\title{
Germination and seedling growth of indigenous aman rice under salt stress
}

\author{
D. Das, M. A. Ali, T. A. Sarkar and M. Y. Ali \\ Agrotechnology Discipline, Khulna University, Khulna, Bangladesh
}

\begin{tabular}{|c|c|}
\hline ARTICLE INFO & Abstract \\
\hline $\begin{array}{l}\text { Article history: } \\
\text { Received: } 17 \text { May } 2017 \\
\text { Accepted: } 29 \text { November } 2017\end{array}$ & $\begin{array}{l}\text { The experiment was conducted at the Agronomy Laboratory of Agrotechnology Discipline, Khulna } \\
\text { University, Khulna to determine the effect of salt stress on germination and seedling growth of indigenous } \\
\text { Aman rice varieties during June, } 2015 \text { to December, 2015. The salt tolerant landraces will be used as } \\
\text { genetic resource for variety development program in future. The factorial experiment consists of two }\end{array}$ \\
\hline $\begin{array}{l}\text { Keywords: } \\
\text { Germination capacity, Seedling } \\
\text { growth, Seedling vigor index }\end{array}$ & $\begin{array}{l}\text { factors such as ten indigenous Aman rice varieties and four levels of salt solutions viz } \mathrm{EC}\left(\mathrm{dS} \mathrm{m}^{-1}\right) \text { of } 5 \text {, } \\
10 \text { and } 15 \text { with control (distilled water). The experiment was laid out in Completely Randomized Design } \\
\text { (CRD) with three replications. The interaction effects between variety and salinity on germination and } \\
\text { seedling growth parameters of indigenous Aman rice varieties were varied significantly. It was found that }\end{array}$ \\
\hline $\begin{array}{l}\text { Correspondence: } \\
\text { D. Das } \\
\text { (debeshdasat@gmail.com) }\end{array}$ & $\begin{array}{l}\text { decreased gradually with increasing salinity. The germination energy and germination speed of most } \\
\text { varieties were drastically reduced at } 10 \mathrm{dS} \mathrm{m} \mathrm{m}^{-1} \text { or higher salinity levels. The germination capacity of } \\
\text { respectively at } 15 \mathrm{dS} \mathrm{m}^{-1} \text { water salinity in laboratory condition. The results revealed that the indigenous } \\
\text { Aman rice varieties named Boushohagi, Shadagotal, Hatibazor, Moinamoti, Motha were performed better } \\
\text { over other varieties considering of germination and seedling growth parameters. }\end{array}$ \\
\hline
\end{tabular}

\section{Introduction}

Rice (Oryza sativa L.) is the principal source of food for more than one third of the world's population. It is the second most important crop in the world after wheat, more than 90 per cent of which is grown in Asia. In Bangladesh, rice is the most important leading cereal crop. The annual cultivated area of rice is 15.03 million hectares and the annual production about 38.34 million metric tons in Bangladesh (BBS, 2016). Rice production is affected by different biotic and abiotic factors flooding, salinity drought, pest and pathogen. Salinity and drought are the most serious challenges to crop production in the world today, particularly in developing countries (Zhou et al. 2007). The higher levels of salt concentration in the germinating media build up the high osmotic pressure of the solution that prevent intake of water for germination. Higher salinity delayed and reduced germination percentage (Ramaden, 1986). Salinity decreased germination percent, root length, coleoptile length and seedling growth (Lallu and Dixit, 2005 and Agnihotri et. al., 2006).

Rice production has significantly increased because of rapid and wide acceptance of high yielding varieties with improvement of irrigation, fertilizer application as well as farming technique. A large number of landraces have been lost by the spread of the elite varieties but these indigenous rice cultivars possess a wide diversity in morphological, physiological and ecological characteristic. Some of the indigenous varieties also have the capacity to tolerate environmental stresses such as salinity during germination and seedling stage.
However, there was a little attention to preserve these land races which might be used as valuable genetic resources for variety improvement program in future. It is necessary to identify the salt tolerant indigenous varieties for successful crop production. In these circumstances, the research was undertaken to determine the effect of salt stress on germination and seedling growth of indigenous Aman rice varieties

\section{Material and Methods}

The experiment was conducted at Agronomy Laboratory of Agrotechnology Discipline, Khulna University, Bangladesh during June 2015 to October 2015. This factorial experiment consists of two factors such as four different concentrations of salt solutions $(0,5,10,15 \mathrm{dS}$ $\left.\mathrm{m}^{-1}\right)$ and ten indigenous Aman rice varieties $\left(\mathrm{V}_{1}=\right.$ Gopalvog, $\mathrm{V}_{2}=$ Hatibazor, $\mathrm{V}_{3}=$ Lalmota, $\mathrm{V}_{4}=$ Hamai, $\mathrm{V}_{5}=$ Khejurchari, $\mathrm{V}_{6}=$ Barjomuri, $\mathrm{V}_{7}=$ Boushohagi, $\mathrm{V}_{8}$ $=$ Shadagotal, $\mathrm{V}_{9}=$ Moinamoti, $\mathrm{V}_{10}=$ Motha. The experiment was carried out in a Completely Randomized Design (CRD) with three replications. Salt solutions of definite level of salinity were prepared by using required amounts of salt $(\mathrm{NaCl})$ dissolving in distilled water (Table 1). The germination tests were conducted at petridishes using distilled water and salt solutions of different concentrations. The recorded data were analyzed statistically with the help of computer package program MSTAT-C and the mean differences were adjudged by Duncan's New Multiple Ranges Test (Gomez and Gomez, 1984). 
Table 1. Salinity levels with corresponding amount of salt $(\mathrm{NaCl})$

\begin{tabular}{ccc}
\hline $\begin{array}{c}\text { Salinity } \\
\text { stress }\end{array}$ & $\begin{array}{c}\text { Water salinity level } \\
(\mathrm{EC}) \mathrm{dS} \mathrm{m}^{-1}\end{array}$ & $\begin{array}{c}\mathrm{aCl}(\mathrm{g}) \text { added per liter } \\
\text { of distilled water }\end{array}$ \\
\hline $\mathrm{S}_{0}$ & 0 (control) & 0.0 \\
$\mathrm{~S}_{1}$ & 5 & 3.20 \\
$\mathrm{~S}_{2}$ & 10 & 6.40 \\
$\mathrm{~S}_{3}$ & 15 & 9.60 \\
\hline
\end{tabular}

\section{Data Collection:}

Germination energy: Percentage of seeds germinating 3 days after sowing (Bam et al., 2006.)

Germination capacity: Percentage of seeds germinating

7 days after sowing (Bam et al., 2006.)

Speed of germination: According to Krishnaswamy \& Seshu (1990) speed of germination was measured by using following formula:

Speed of germination $(\%)=$

$$
\frac{\text { Number of seeds germinated at } 72 \mathrm{~h}}{\text { Number of seeds germinated at } 168 \mathrm{~h}} \times 100
$$

Seedling vigor index (SVI): According to Abdul and Anderson (1973) seedling vigor index was measured by the following equation:

Seedling vigor index $=$ (average shoot length + average root length) $\times$ germination percentage
Root and shoot length: Five seedlings were sampled randomly from each petridish to measure root and shoot length.

\section{Results and Discussion}

Effect of variety on germination and seedling growth parameters of indigenous Aman rice

All the studied parameters viz, germination energy, germination capacity, seedling vigor index, root length $(\mathrm{cm})$ and shoot length $(\mathrm{cm})$ in the tested varieties differed significantly. The highest germination energy was found in Boushohagi (97.83\%) which was statistically similar to Motha $(96.50 \%)$ whereas the lowest was recorded in Gopalvog (56.67\%). The highest germination capacity was found in Barjomuri (99.83\%) and Boushohagi (99.83\%) which was statistically similar to Shadagotal (99.33\%), Motha (99.5\%), Hatibazor (99\%), Lalmota (98\%), and Moinamoti (97.5\%) but the lowest germination capacity $(90.33 \%)$ was observed in Khejurchari which was statistically similar to Hamai $(91.67 \%)$ (Table 2).

Germination speed was differed significantly among the varieties. The Germination speed ranged from 58.99\% to 97.99\%. The variety Boushohagi (97.99\%) showed highest germination speed whereas the lowest was found in Gopalvog $(58.99 \%)$ (Table 2).

Table 2. Effect of variety on germination and seedling growth parameters of indigenous Aman rice

\begin{tabular}{lcccccc}
\hline Variety & $\begin{array}{c}\text { Germination } \\
\text { energy }(\%)\end{array}$ & $\begin{array}{c}\text { Germination } \\
\text { capacity }(\%)\end{array}$ & $\begin{array}{c}\text { Germination } \\
\text { speed }(\%)\end{array}$ & $\begin{array}{c}\text { Seedling vigor } \\
\text { index }\end{array}$ & $\begin{array}{c}\text { Root length } \\
(\mathrm{cm})\end{array}$ & $\begin{array}{c}\text { Shoot length } \\
(\mathrm{cm})\end{array}$ \\
\hline Gopalvog & $56.67 \mathrm{~g}$ & $95.33 \mathrm{~b}$ & $58.99 \mathrm{e}$ & $447.2 \mathrm{~d}$ & $2.02 \mathrm{~d}$ & $2.6 \mathrm{~cd}$ \\
Hatibazor & $72.83 \mathrm{de}$ & $99 \mathrm{a}$ & $73.34 \mathrm{~cd}$ & $423.4 \mathrm{~d}$ & $1.52 \mathrm{~d}$ & $2.74 \mathrm{~b}-\mathrm{d}$ \\
Lalmota & $68.33 \mathrm{ef}$ & $98 \mathrm{ab}$ & $69.52 \mathrm{~d}$ & $631.8 \mathrm{c}$ & $3.16 \mathrm{c}$ & $3.25 \mathrm{a}-\mathrm{c}$ \\
Hamai & $65.17 \mathrm{f}$ & $91.67 \mathrm{c}$ & $70.44 \mathrm{~cd}$ & $434.1 \mathrm{~d}$ & $1.98 \mathrm{~d}$ & $2.72 \mathrm{~b}-\mathrm{d}$ \\
Khejurchari & $67 \mathrm{ef}$ & $90.33 \mathrm{c}$ & $73.40 \mathrm{~cd}$ & $279.3 \mathrm{e}$ & $1.13 \mathrm{~d}$ & $1.91 \mathrm{~d}$ \\
Barjomuri & $81.17 \mathrm{c}$ & $99.83 \mathrm{a}$ & $81.22 \mathrm{~b}$ & $879.5 \mathrm{a}$ & $5.09 \mathrm{~b}$ & $3.7 \mathrm{ab}$ \\
Boushohagi & $97.83 \mathrm{a}$ & $99.83 \mathrm{a}$ & $97.99 \mathrm{a}$ & $854.3 \mathrm{ab}$ & $5.04 \mathrm{~b}$ & $3.51 \mathrm{a}-\mathrm{c}$ \\
Shadagotal & $76.83 \mathrm{~cd}$ & $99.33 \mathrm{a}$ & $77.45 \mathrm{bc}$ & $719.7 \mathrm{bc}$ & $4.24 \mathrm{bc}$ & $3.01 \mathrm{bc}$ \\
Moinamoti & $91 \mathrm{~b}$ & $97.5 \mathrm{ab}$ & $93.31 \mathrm{a}$ & $1004 \mathrm{a}$ & $6.72 \mathrm{a}$ & $3.58 \mathrm{a}-\mathrm{c}$ \\
Motha & $96.50 \mathrm{ab}$ & $99.5 \mathrm{a}$ & $96.96 \mathrm{a}$ & $885.2 \mathrm{a}$ & $4.76 \mathrm{~b}$ & $4.12 \mathrm{a}$ \\
LS. & $* *$ & $* *$ & $* *$ & $* *$ & $* *$ & $* *$ \\
CV. $(\%)$ & 6.35 & 2.19 & 6.43 & 16.81 & 24.04 & 21.94 \\
\hline
\end{tabular}

Means with the same letter in the column do not differed significantly, $* *=$ Significant at $1 \%$ level, $*=$ Significant at $5 \%$ level, CV. $(\%)=$ Co-efficient of variation, LS. = Level of significant.

Means are the average of all parameters derived from ten cultivars with three replications

The seedling of Moinamoti (1004) is highly vigor which was followed by Motha (885.2), Barjomuri (879.5), Boushohagi (854.3), Shadagotal (719.7), Lalmota (631.8) whereas the Khejurchari (279.3) was poorly vigor. The variation in germination parameters among varieties may be due to variation of genetype. The results obtained from this experiment were supported and coincides with Anbumalarmathi and Metha (2013), Hakim et al. (2010).
The shoot and root length of tested rice varieties differed significantly. The root length ranged from $1.13 \mathrm{~cm}$ to $6.13 \mathrm{~cm}$. The highest root length was observed in Moinamoti $(6.72 \mathrm{~cm})$ but the lowest root length was found in Khejurchari $(1.13 \mathrm{~cm})$ (Table 2).

The shoot length of the tested variety varied from 1.91 $\mathrm{cm}$ to $4.12 \mathrm{~cm}$. The highest shoot length was recorded in Motha $(4.12 \mathrm{~cm})$ which was statistically similar to Barjomuri $(3.7 \mathrm{~cm})$, Moinamoti $(3.58 \mathrm{~cm})$, Boushohagi 
$(3.51 \mathrm{~cm})$ and Lalmota $(3.25 \mathrm{~cm})$ whereas, the lowest shoot length was noticed in Khejurchari $(1.91 \mathrm{~cm})$ (Table 2). From the present investigation it was observed that the variation in germination parameters among different varieties might be due to genetic diversity which were supported by the experimental findings of Horie et al. (2012) and Hossain (2014).

\section{Effect of salinity on germination and seedling growth} parameters of indigenous Aman rice

There were significant effects of salt stress on germination and seedling growth parameters of rice.
Germination parameters showed downward tendency with increasing salinity level. It was found that highest germination energy (\%), germination capacity (\%) and germination speed were observed at control which was decreased gradually with increasing salinity upto $15 \mathrm{dS}$ $\mathrm{m}^{-1}$ (Fig. 1). The figure indicates that the germination energy and germination speed at control is approximately double from those of the highest salinity level $\left(15 \mathrm{dS} \mathrm{m}^{-1}\right)$.

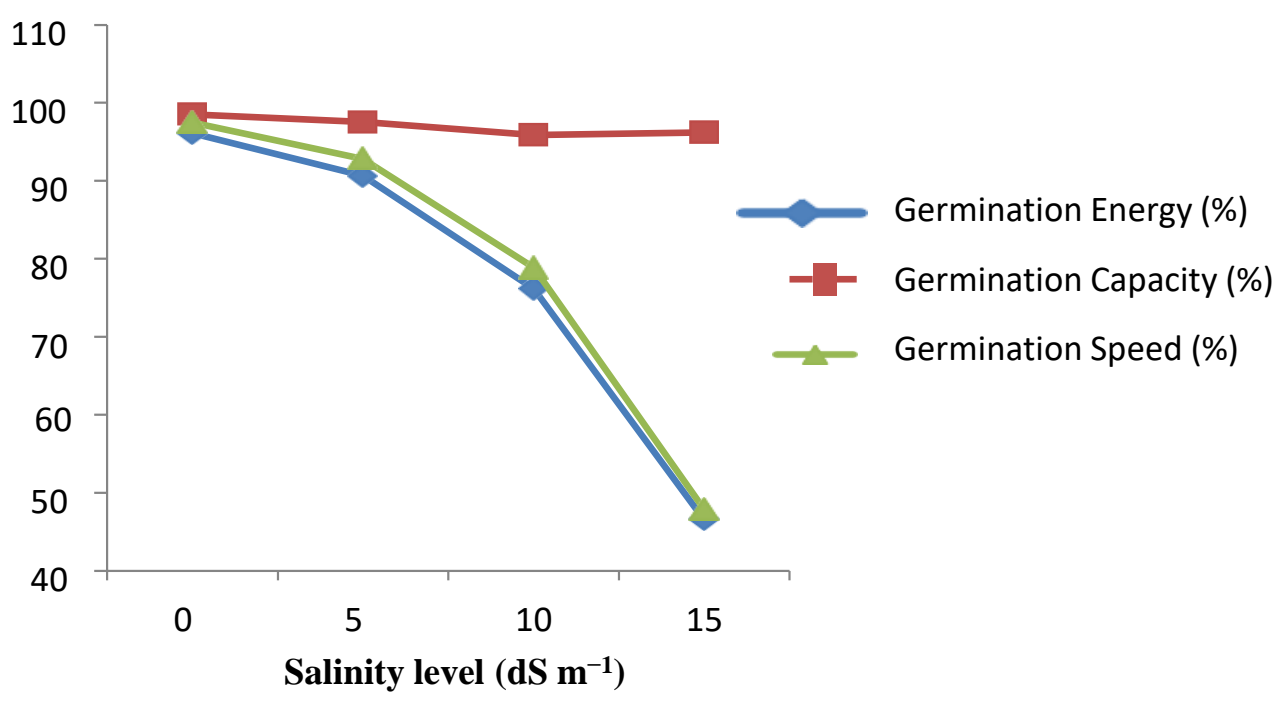

Fig. 1. Effect of salinity on germination parameters of indigenous Aman rice varieties

The effect of salt stress on root and shoot length was highly significant. The root length of the tested varieties ranged from $2.83 \mathrm{~cm}$ to $4.06 \mathrm{~cm}$ under different salinity levels. The highest root length $(4.06 \mathrm{~cm})$ was observed at control but the lowest $(2.83 \mathrm{~cm})$ was found at $\mathrm{S}_{3}(15$ $\left.\mathrm{dS} \mathrm{m} \mathrm{m}^{-1}\right)$. The highest shoot length $(4.1 \mathrm{~cm})$ was observed at control which was approximately double of the shoot length $(2.12 \mathrm{~cm})$ at $\mathrm{S}_{3}\left(15 \mathrm{dS} \mathrm{m} \mathrm{m}^{-1}\right)$ (Fig. 2). The figure indicates that shoot length was more affected by salinity than root length. During germination of most seeds reserves are degraded by amylases, phosphorylases and glucosidase and much of the hydrolysis products are transported to the embryo for growth (Sun and Henson, 1991). This mobilization of simple sugar is affected by salt stress. High concentrations of $\mathrm{NaCl}$ showed strong inhibition of germination, root length as well as shoot length in compare to lower concentrations. The results of this experiment coincided by Theerakulpisut et al. (2005) and they stated that the dry weight of shoots and roots were highly correlated with the salinity.
Interaction effect between variety and salinity on germination and seedling growth parameters of indigenous Aman rice

\section{Germination energy}

Germination energy (\%) varied from $12.67 \%$ to $100 \%$ due to the interaction between variety and different levels of salinity. The highest germination energy was found in Boushohagi (100\%) at control but the lowest germination energy was found in Gopalvog (12.67\%) at $15 \mathrm{dS} \mathrm{m}$. The germination energy were significantly $(\mathrm{P}<0.01)$ reduced with increasing salinity and drastically reduced at $10 \mathrm{dS} \mathrm{m}^{-1}$ and higher (Table 3 ).

\section{Germination capacity}

Germination capacity (\%) ranged from $86 \%$ to $100.00 \%$. The variety Hatibazor (100.00\%), Barjomuri (100.00\%), Boushohagi (100.00\%), Shadagotal (100.00\%), Motha $(100.00 \%)$ showed cent percent germination at control. The germination capacity of most varieties were significantly $(\mathrm{P}<0.01)$ reduced at $5 \mathrm{dS} \mathrm{m} \mathrm{m}^{-1}$ and higher (Table 3). 


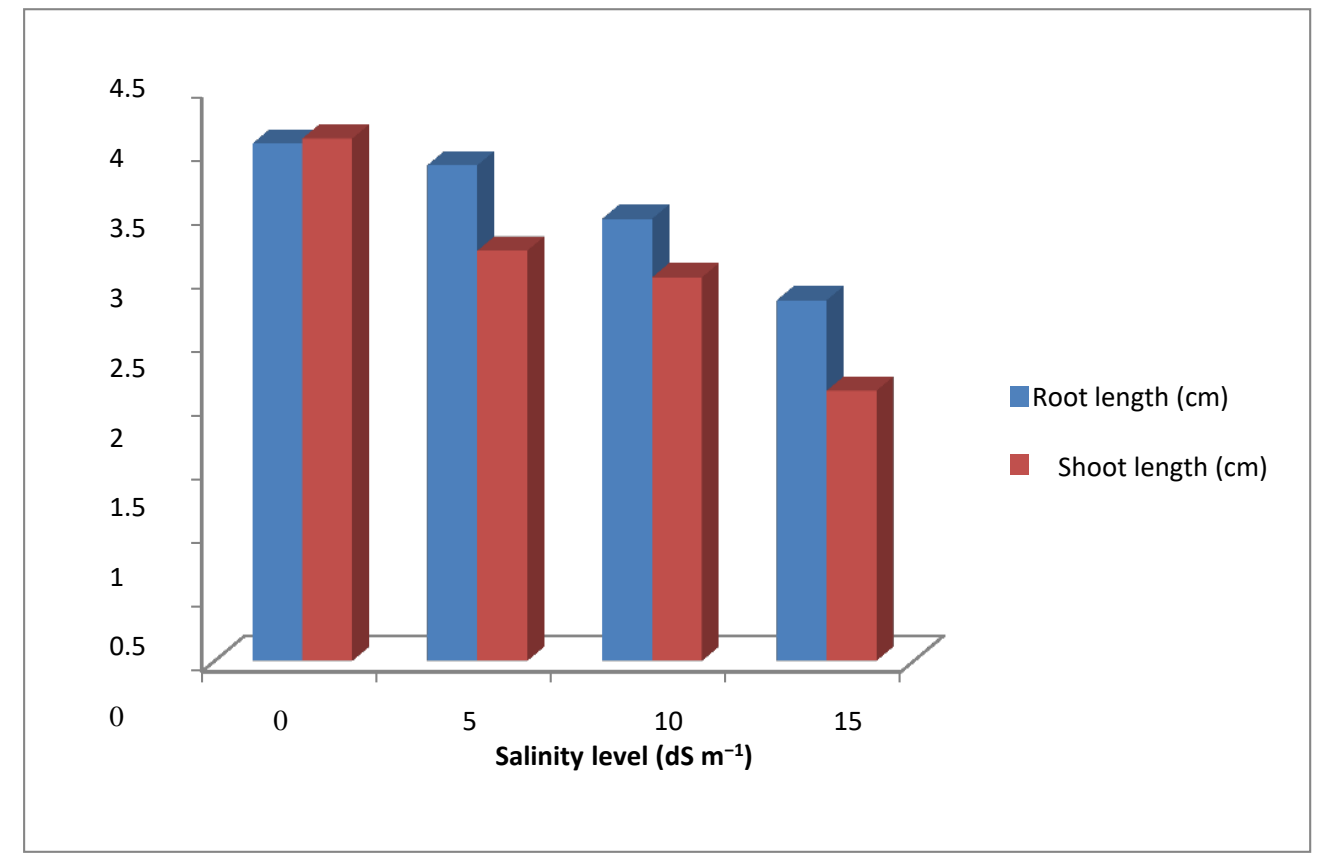

Fig. 2. Effect of salinity on root and shoot length of indigenous Aman rice varieties

\section{Germination speed}

The interaction effect between variety and salinity on germination speed was varied significantly and ranged from $13 \%$ to $100 \%$. The maximum speed of germination was Boushohagi (100\%) at control and $5 \mathrm{dS} \mathrm{m}^{-1}$ salinity level but the minimum was Gopalvog (13\%) at $15 \mathrm{dS}$ $\mathrm{m}^{-1}$ sanity level (Table 3).

\section{Seedling vigor index}

The seedling vigor index of different rice varieties were varied significantly. It was found that the variety of Motha was highly vigor followed by Barjomuri, Moinamoti, Boushohagi, Shadagotal but the variety khejurchari was poorly vigor (Table 3 ). The variation of seedling vigor might be due to genotypic differences which was supported by Hasegawa et al. (2000) and stated that salt stress and tolerance in several species including rice might be due to the expression of specific genes or completely suppress the expression of others.

\section{Root length}

The root length of tested varieties was varied from 0.5 $\mathrm{cm}$ to $7.91 \mathrm{~cm}$. The highest root length was recorded in Moinamoti $(7.91 \mathrm{~cm})$ and followed by Motha, Gopalvog, and Boushohagi at control whereas the lowest root length was noticed in Hatibazor $(0.5 \mathrm{~cm})$ at $15 \mathrm{dS}$ $\mathrm{m}^{-1}$. It was found that root length was adversely affected by salinity and reduction of root length was more prominent than shoot (Table 3). Our findings were supported by Akhtar and Azhar (2001) and stated that root lengths of 11 varieties were affected considerably in comparison with their shoot lengths, also shown that root length is the most sensitive part of plant under salt stress.

\section{Shoot length}

The shoot length obtained from the interaction effect between variety and salinity varied from $1.46 \mathrm{~cm}$ to 5.29 $\mathrm{cm}$. The highest shoot length was found in Boushohagi $(5.29 \mathrm{~cm})$ at control but the lowest shoot length was noticed in Khejurchari $(1.46 \mathrm{~cm})$ at $15 \mathrm{dS} \mathrm{m}^{-1}$ (Table 3). It was found that the adverse effect of salinity on the root and shoot length might be due to the lower uptakes of water and nutrients from the growing media. The growing media possesses higher concentration of salts which may causes imbalances in osmotic pressure. The reduced growth under salt stress might be due to inhibition of transport of essential nutrient to the shoot (Tarmatt and Munns, 1986) Dagar et.al., 2004. 
Table 3. Interaction effect between variety and salinity on germination and seedling growth parameters of indigenous Aman rice

\begin{tabular}{|c|c|c|c|c|c|c|c|}
\hline \multicolumn{2}{|c|}{ Treatment Combination } & \multirow{2}{*}{$\begin{array}{c}\text { Germination } \\
\text { energy }(\%)\end{array}$} & \multirow{2}{*}{$\begin{array}{l}\text { Germination } \\
\text { capacity }(\%)\end{array}$} & \multirow{2}{*}{$\begin{array}{c}\text { Germination } \\
\text { speed }(\%)\end{array}$} & \multirow{2}{*}{$\begin{array}{c}\text { Seedling } \\
\text { vigor index }\end{array}$} & \multirow{2}{*}{$\begin{array}{l}\text { Root length } \\
(\mathrm{cm})\end{array}$} & \multirow{2}{*}{$\begin{array}{l}\text { Shoot length } \\
(\mathrm{cm})\end{array}$} \\
\hline Salinity $\left(\mathrm{dSm}^{-1}\right)$ & Variety & & & & & & \\
\hline \multirow{10}{*}{, } & Gopalvog & $97.33 a-c$ & $99.33 \mathrm{ab}$ & $97.99 \mathrm{a}$ & $872.3 a-e$ & $5.2 \mathrm{c}-\mathrm{g}$ & 3.58 \\
\hline & Hatibazor & $98.67 \mathrm{ab}$ & $100 \mathrm{a}$ & $97.99 \mathrm{a}$ & $553.3 \mathrm{f}-\mathrm{j}$ & $2.37 i-p$ & 3.16 \\
\hline & Lalmota & $94.67 \mathrm{a}-\mathrm{c}$ & $99.33 \mathrm{ab}$ & $95.33 \mathrm{ab}$ & $770.9 \mathrm{~d}-\mathrm{g}$ & $3.82 \mathrm{e}-\mathrm{m}$ & 3.93 \\
\hline & Hamai & $88.67 a-d$ & $94 b-e$ & $94.37 \mathrm{ab}$ & $445.1 \mathrm{e}-\mathrm{i}$ & $2.74 h-p$ & 4.12 \\
\hline & khejurchari & $91.33 \mathrm{a}-\mathrm{d}$ & $95.33 \mathrm{a}-\mathrm{e}$ & $95.78 \mathrm{ab}$ & $492.9 \mathrm{~g}-\mathrm{k}$ & $2.3 \mathrm{k}-\mathrm{p}$ & 2.83 \\
\hline & Barjomuri & $99.33 \mathrm{a}$ & $100 \mathrm{a}$ & $99.33 \mathrm{a}$ & $841 b-e$ & $6.83 \mathrm{a}-\mathrm{c}$ & 4.08 \\
\hline & Boushohagi & $100 \mathrm{a}$ & $100 \mathrm{a}$ & $100.0 \mathrm{a}$ & $1004 a-d$ & $4.75 \mathrm{c}-\mathrm{h}$ & 5.29 \\
\hline & Shadagotal & $96 a-c$ & $100 \mathrm{a}$ & $96.00 \mathrm{ab}$ & $920.8 \mathrm{a}-\mathrm{e}$ & $4.62 c-j$ & 4.58 \\
\hline & Moinamoti & $95.33 \mathrm{a}-\mathrm{c}$ & $98 \mathrm{a}-\mathrm{c}$ & $97.27 \mathrm{a}$ & $1260.28 \mathrm{a}$ & $7.91 \mathrm{a}$ & 4.95 \\
\hline & Motha & $99.33 \mathrm{a}$ & $100 \mathrm{a}$ & $99.33 \mathrm{a}$ & $845.7 b-e$ & $5.66 b-f$ & 4.5 \\
\hline \multirow{10}{*}{5} & Gopalvog & $75.33 \mathrm{e}-\mathrm{g}$ & $96.67 \mathrm{a}-\mathrm{d}$ & $78.08 \mathrm{c}-\mathrm{e}$ & $359 \mathrm{i}-1$ & $1.16 o p$ & 2.54 \\
\hline & Hatibazor & $88 \mathrm{a}-\mathrm{d}$ & $99.33 \mathrm{ab}$ & $88.63 a-c$ & $525.2 \mathrm{f}-\mathrm{j}$ & $2.37 j-p$ & 2.91 \\
\hline & Lalmota & $90.67 a-d$ & $98.67 \mathrm{a}-\mathrm{c}$ & $91.83 \mathrm{ab}$ & $758.4 d-h$ & $4.1 \mathrm{e}-1$ & 3.56 \\
\hline & Hamai & $85.33 b-e$ & $93.33 c-f$ & $91.39 \mathrm{ab}$ & $403 i-1$ & $1.45 n-p$ & 2.84 \\
\hline & khejurchari & $84.67 \mathrm{c}-\mathrm{e}$ & $91.33 \mathrm{e}-\mathrm{g}$ & $92.72 \mathrm{ab}$ & $226.9 \mathrm{kl}$ & $0.7 \mathrm{p}$ & 1.79 \\
\hline & Barjomuri & $96 a-c$ & $100 \mathrm{a}$ & $96.00 \mathrm{ab}$ & 926.3a-e & $5.37 \mathrm{~b}-\mathrm{g}$ & 3.89 \\
\hline & Boushohagi & $99.97 \mathrm{a}$ & $100 \mathrm{a}$ & $100.0 \mathrm{a}$ & $1014 a-d$ & $6.79 a-c$ & 3.34 \\
\hline & Shadagotal & $91.33 \mathrm{a}-\mathrm{d}$ & $100 \mathrm{a}$ & $93.18 \mathrm{ab}$ & $807 c-f$ & $5.16 \mathrm{c}-\mathrm{g}$ & 2.91 \\
\hline & Moinamoti & $96 a-c$ & $97.33 \mathrm{ac}$ & $98.63 a$ & $1112.48 \mathrm{a}-\mathrm{c}$ & $7.44 \mathrm{ab}$ & 3.99 \\
\hline & Motha & $98.67 \mathrm{ab}$ & $100 \mathrm{a}$ & $98.67 \mathrm{a}$ & $908 a-e$ & $4.41 \mathrm{~d}-\mathrm{k}$ & 4.66 \\
\hline \multirow{10}{*}{10} & Gopalvog & $41.43 \mathrm{j}$ & $88 \mathrm{gh}$ & $46.97 \mathrm{~g}$ & $260.3 j-1$ & $0.7 p$ & 2.25 \\
\hline & Hatibazor & $70.67 f-g$ & $99.33 \mathrm{ab}$ & $71.10 \mathrm{~d}-\mathrm{f}$ & $344.7 \mathrm{j}-1$ & $0.83 p$ & 2.96 \\
\hline & Lalmota & $58 \mathrm{i}$ & $96 a-e$ & $60.35 f$ & $525.4 \mathrm{f}-\mathrm{j}$ & $2.26 \mathrm{k}-\mathrm{p}$ & 3.18 \\
\hline & Hamai & $62.67 \mathrm{hi}$ & $91.33 \mathrm{~d}-\mathrm{g}$ & 68.68ef & $387.6 \mathrm{i}-1$ & 2.021-p & 2.21 \\
\hline & khejurchari & $64.67 \mathrm{~g}-\mathrm{i}$ & $88.67 f-h$ & $73.23 \mathrm{de}$ & 198.21 & $0.69 \mathrm{p}$ & 1.55 \\
\hline & Barjomuri & $91.33 \mathrm{a}-\mathrm{d}$ & $100 \mathrm{a}$ & $91.33 \mathrm{ab}$ & $982.7 \mathrm{a}-\mathrm{d}$ & $5.04 \mathrm{c}-\mathrm{g}$ & 3.78 \\
\hline & Boushohagi & $99.33 \mathrm{a}$ & $100 \mathrm{a}$ & $99.33 \mathrm{a}$ & $849.3 \mathrm{~b}-\mathrm{e}$ & $5.08 \mathrm{c}-\mathrm{g}$ & 3.41 \\
\hline & Shadagotal & 87.33a-e & $99.33 \mathrm{ab}$ & $87.95 a-c$ & $642.1 \mathrm{e}-\mathrm{i}$ & $3.87 \mathrm{e}-\mathrm{m}$ & 2.58 \\
\hline & Moinamoti & $92 a-d$ & $97.33 \mathrm{a}-\mathrm{c}$ & $94.51 \mathrm{ab}$ & $1105.4 \mathrm{a}$ & $6.54 a-d$ & 3.79 \\
\hline & Motha & $94 a-c$ & $98.67 \mathrm{a}-\mathrm{c}$ & $95.19 \mathrm{ab}$ & $975.6 a-d$ & $5.04 \mathrm{c}-\mathrm{g}$ & 4.21 \\
\hline \multirow{10}{*}{15} & Gopalvog & $12.67 \mathrm{~m}$ & $77.33 \mathrm{i}-\mathrm{j}$ & $16 \mathrm{i}$ & $297.1 \mathrm{j}-1$ & $1 \mathrm{p}$ & 2.04 \\
\hline & Hatibazor & $34 j-1$ & $97.66 \mathrm{a}-\mathrm{c}$ & $34.95 \mathrm{gh}$ & $270.3 \mathrm{j}-1$ & $0.5 \mathrm{p}$ & 1.94 \\
\hline & Lalmota & $30 \mathrm{j}-1$ & $88 \mathrm{gh}$ & $34.55 \mathrm{~h}$ & $472.5 \mathrm{~h}-1$ & $2.48 \mathrm{i}-\mathrm{p}$ & 2.33 \\
\hline & Hamai & 241 & $88 \mathrm{gh}$ & $27.33 \mathrm{~h}$ & $300.7 \mathrm{j}-1$ & $1.7 \mathrm{~m}-\mathrm{p}$ & 1.71 \\
\hline & khejurchari & $27.33 \mathrm{kl}$ & $76 \mathrm{jk}$ & $31.87 \mathrm{~h}$ & 197.81 & $0.84 \mathrm{p}$ & 1.46 \\
\hline & Barjomuri & $38 \mathrm{jl}$ & $89.33 \mathrm{f}-\mathrm{h}$ & $38.23 \mathrm{gh}$ & $768.1 \mathrm{~d}-\mathrm{g}$ & $4.64 \mathrm{c}-\mathrm{i}$ & 3.08 \\
\hline & Boushohagi & $92 a-d$ & $99.33 \mathrm{ab}$ & $92.63 \mathrm{ab}$ & $550.2 \mathrm{f}-\mathrm{j}$ & $3.54 \mathrm{f}-\mathrm{n}$ & 1.99 \\
\hline & Shadagotal & $32.67 \mathrm{j}-1$ & $98 \mathrm{a}-\mathrm{c}$ & $33.33 \mathrm{~h}$ & $513.52 \mathrm{f}-\mathrm{j}$ & $3.29 \mathrm{~g}-\mathrm{o}$ & 1.95 \\
\hline & Moinamoti & $80.67 d-f$ & $93.33 \mathrm{a}-\mathrm{c}$ & $82.84 b-d$ & $640.2 \mathrm{e}-\mathrm{i}$ & $4.99 \mathrm{c}-\mathrm{h}$ & 1.58 \\
\hline & Motha & $84 \mathrm{c}-\mathrm{e}$ & $87.33 \mathrm{gh}$ & $94.64 \mathrm{ab}$ & $811.5 c-f$ & $3.95 \mathrm{e}-\mathrm{m}$ & 3.13 \\
\hline LS. & & $* *$ & $* *$ & $* *$ & $* *$ & $* *$ & $\mathrm{NS}$ \\
\hline $\mathrm{CV}(\%)$ & & 6.35 & 2.19 & 6.43 & 16.81 & 24.04 & 21.94 \\
\hline
\end{tabular}

Means with the same letter in the column do not differed significantly; $* *=$ Level of significant at $1 \%$ level; $*=$ Level of significant at $5 \%$ level; LS $(\%)=$ Level of Significance; CV. $(\%)=$ Co-efficient of variation; Where, $S_{0}=$ Control; $\quad S_{1}=5 \mathrm{dS}$ $\mathrm{m}^{-1} ; \mathrm{S}_{2}=10 \mathrm{dS} \mathrm{m}{ }^{-1} ; \mathrm{S}_{3}=15 \mathrm{dS} \mathrm{m}^{-1}$

Means are the average of 40 treatments combination derived from ten cultivars and four salinity stresses with three replications

\section{Conclusion}

Germination and seedling growth of indigenous Aman rice were significantly affected by salt stress. Germination percentage (\%), germination energy (\%), germination capacity $(\%)$, germination speed $(\%)$, root length $(\mathrm{cm})$, shoot length $(\mathrm{cm})$, seedling vigor index were declined gradually with increasing salinity. The variable response was found by the interaction between varieties to salinity. The variety named Boushohagi, Shadagotal, Hatibazor, Moinamoti, Motha were might be considered as superior to others variety based on their germination and seedling growth performance.

\section{Acknowledgement}

The authors would like to thank Agrotechnology Discipline for the logistic support and especial thanks to the Ministry of Education, Bangladesh for financial support throughout the period of experiment. The authors would like to thank Md. Samsol Alam, Md. Taohiduzzaman, Nevanon Kumar Roy, Dhiman Adhikary, Md. Habibur Rahman for their technical assistance. 


\section{References}

Abdul. A.A. and Anderson, J.D. 1973. Vigor Determination in Soybean Seed by Multiple Criteria. Crop Sci. Vol. 1(3), pp 630- 633 .

Agnihotri, R.K., Palni, L.M.S. and Pandey, D.K. 2006. Screening of land races of rice under cultivation in Kumaun Himalayan for salinity stress during germination and early seedling growth. Indian J. Plant Physiol., 11 (30: 262-272.

Akhtar, J. and Azhar, F.M. 2001. Response of Gossypium hirsutum L. hybrids to $\mathrm{NaCl}$ salinity at seedling stage. Int. J. Agri. Biol, 3: 233-235.

Anbumalarmathi, J. and Mehta, P. 2013. Effect of Salt Stress on germination of indica rice varieties. European J. Biol. Sci., pp: $1-6$.

Bam, R.K., Kumaga, F.K., Ofori, K. and Asieudu, E.A. 2006. Germination, vigor and dehydrogenase activity of naturally aged rice (Oryza sativa L.) seeds soaked in potassium and phosphorous salts. Asian J. Plant Sci., 5: 948-955.

BBS. 2016. Agricultural Statistic in Bangladesh. Bangladesh Bureau of Statistics, Agriculture Wing.

Dagar, J.C., Bhagwan, H. and Kumar, Y. 2004. Effect of growth performance and biochemical content of salvadorapersica when irrigated with water of different salinity. Indian $J$. Plant Physiol., 9(3): 234-238.

Gomez, K.A. and Gomez, A.A., 1984. Statistical procedures for agricultural research. John Wiley \& Sons.

Hakim, M.A., Juraimi, A.S., Begum, M., Hanif, M.M., Ismail, M.R. and Selamat, A. 2010. Effect of salt stress on germination and early seedling growth of rice (Oryza sativa L.). African J. Biotech., 9(13): 1911-1918.

Hasegawa, P.M., Bressan, R.A., Zhu, J.K. and Bonhert, H.J. 2000. Plant cellular and molecular responses to high salinity. Annual Rev. of Plant Physiol. and Plant Molecular Biol., 51: 463-499.
Horie, T., Karahara, I. and Katsuhara, M. 2012. Salinity tolerance mechanisms in glycophytes: An overview with the central focus on rice plants. Rice 5(1): 11 .

Hossain, S., 2014. Findings of Rice Biodiversity by farmer participatory trials and selection of Rice variety suited to environment" (In Bangla), pp. 45-49, (proceeding of workshop on rice Diversity Evaluation in South West of Bangladesh).

Krishnaswamy, V and Seshu, DV .1990. Germination after ccelerate aging associated characters in rice varieties. Seed Sci. Tech., 8: 147-150

Lallu and Dixit, R.K. 2005. Salt tolerance of Mustard genotype at seedling stage. Indian J. Pl. Physiol., 14 (2): 33-35.

Ramden, H.A., Niemi, S.A. and Hadathi,Y.K.A. 1986. Salinity and seed germination of corn and soyabean. Iraqui J. Agri. Sci. 4(2): 97-102.

Sun, Z. \& Henson, C.A. 1991. A quantitative assessment of the importance of barleyseed a-amylase, P-amylase, debranching enzyme, and a-glucosidase in starch degradation. Arch Biochem \& Biophys., 284: 298-305.

Tarmatt, A. and Munns, R.1986 .Use of concentrated micronutrient solution to separate osmotic from $\mathrm{NaCl}$ specific effects on plant growth. Aust. J. Plant Physiol., 13: 509-522.

Theerakulpisut, P., Bunnag,S. and Kong-Ngern, K. 2005. Genetic diversity, salinity tolerance and physiological responses to $\mathrm{NaCl}$ of six rice (Oryza sativa L.) cultivars. Asian J. Plant Sci., 4(6): 562-573.

Zhou J., Wang, X., Jiao, Y., Qin, Y., Liu X., He K., Chen Ch., Ma L., Wang J., Xiong, L., Zhang, Q., Fan L. and Deng, X.W. 2007. Global genome expression analysis of rice in response to drought and high-salinity stresses in shoot, flag leaf, and panicle. J. Plant Mol. Biol., 63: 591-608. 